\title{
GAMBARAN KEBIASAAN KONSUMSI MIE INSTAN PADA ANAK USIA 7-12 TAHUN Studi di Sekolah Dasar Kanisius Tlogosari Kulon Semarang
}

\author{
Dewi Kristina Ratnasari, Yekti Wirawanni*) \\ Program Studi Ilmu Gizi Fakultas Kedokteran Universitas Diponegoro \\ Jl.Dr.Sutomo No.14, Semarang, Telp (024) 8453708, Email : gizifk@undip.ac.id
}

\begin{abstract}
Background: instant noodles is popular among societies, because instant noodles is practical, cheap and delicious. The objective of this study is to describe the habit of consuming instant noodles in children.

Method: This study uses descriptive study. Samples are 80 students of class 1-6 in Kanisius State

Elementary School in Tlogosari Kulon, Semarang that was selected by proportional random sampling method. Datas were collected using questionnaire and food recall table for 3 days .

Result:

Conclusion: The students in Kanisius State Elementary School in Tlogosari Kulon, Semarang are often consuming instant noodles as snacks or main food. There are many students consuming instant noodles without adding another ingredients to complement its nutrition, and natrium intake contribution in consuming instant noodles is high.
\end{abstract}

Key Words: contribution; children age 7-12 years old; instant noodles

\section{ABSTRAK}

Latar Belakang: Mie instan disukai berbagai kalangan karena praktis, harga terjangkau dan rasanya yang enak. Penelitian ini bertujuan untuk mendeskripsikan kebiasaan mengkonsumsi mie instan pada anak.

Metode: Jenis penelitian ini adalah penelitian deskriptif. Subyek ini adalah siswa kelas 1-6 di SDN Kanisius Tlogosari Kulon. Pengambilan sampel dilakukan dengan simple random sampling. Jumlah sampel sebanyak 80 siswa. Pengambilan data menggunakan kuesioner dan tabel food recall selama 3 hari.

Hasil: jumlah mie instan yang dikonsumsi selama 3 hari recall sebanyak 25,0\% subyek mengkonsumsi mie instan $<3$ bungkus, terdapat 10,0 subyek memiliki frekuensi kebiasaan mengkonsumsi mie instan >4xseminggu. 62,5\% subyek memiliki kebiasaan mengkonsumsi mie instan tanpa menambahakan bahan makanan lain. Sebanyak 46,3\% subyek memiliki kontribusi asupan energi <20\% dari asupan energi total, 50,0\% subyek memiliki kontribusi asupan protein mie instan $<15 \%$ dari asupan protein total, 47,5 subyek memiliki kontribusi asupan natrium mie instan sebanyak $>70 \%$ dari asupan natrium total.

Simpulan: Siswa-siswi di SD Kanisius Tlogosari Kulon Semarang ini sering mengkonsumsi mie instan sebagai makanan jajanan maupun sebagai makanan pokok. Masih banyak siswa -siswi yang mengkonsumsi mie instan tanpa menambahkan bahan makanan lain sebagai pelengkap kebutuhan gizinya dan kontribusi asupan natrium mie instan masih cukup tinggi.

Kata Kunci: Kontribusi; anak usia 7-12 tahun; mie instan

\section{PENDAHULUAN}

Anak usia 7-12 tahun merupakan anak usia sekolah dasar dimana mereka pada masa ini mereka mengalami pertumbuhan yang tetap dan memiliki karakteristik mulai ingin mencoba mengembangkan kemandirian dan menentukan keinginannya sendiri. Pada usia ini anak lebih banyak menghabiskan waktu untuk kegiatan di sekolah dengan berbagai aktivitas sekolah yang cukup padat sehingga terjadi peningkatan nafsu makan secara alamiah. ${ }^{1,2}$ Anak juga sudah pandai menentukan makanan yang mereka sukai karena sudah mengenal lingkungan, biasanya mereka lebih menyukai makanan instan atau fast food yang banyak mengandung karbohidrat dan vetsin sebagai penyedap rasa. ${ }^{3}$ Kebiasaan makan yang sering menyantap makanan siap saji akibat gencarnya iklan dan ajakan teman yang dapat mempengaruhi status gizi anak karena makanan instan seperti mie instan ini cenderung rendah serat, rendah vitamin serta mineral, tapi tinggi kalori, tinggi lemak serta tinggi garam natrium serta kolestrol. ${ }^{4}$

Dalam sebungkus mie instan terdapat kandungan bahan tambahan makanan seperti MSG, sodium tripolyphosphat sebagai bahan pengenyal dan bahan pengawet seperti natrium benzoat serta bahan pewarna tartrazine yellow sebagai pewarna kuning pada mie instan. ${ }^{5}$ Asupan tinggi natrium merupakan salah satu faktor risiko terjadinya 
hipertensi. Kebutuhan natrium menurut World Health Organization (WHO), perlu adanya pembatasan konsumsi garam dapur hingga 6 gram sehari (ekivalen dengan $2400 \mathrm{mg}$ natrium). ${ }^{6}$ Selain itu terdapat kandungan fosfat yang membuat tekstur mie instan lebih kenyal, dapat mempertahankan rasa pada bumbu dan membuat air rebusan mie instan lebih jernih. ${ }^{7}$

Sekolah Dasar Kanisius Tlogosari Kulon yang sebagian besar muridnya berasal dari kalangan keluarga yang memiliki ekonomi menengah kebawah. Lokasi sekolah ini berada ditengah perumahan penduduk. Sekolah memiliki kantin sekolah sendiri yang menjual berbagai makanan jajanan, namun di luar halaman sekolah masih banyak terdapat penjual jajanan, salah satunya penjual mie instan. penelitian ini bertujuan untuk mendeskripsikan gambaran kebiasaan konsumsi mie instan siswa-siswi di Sekolah Dasar Negeri Kanisius Tlogosari Kulon Semarang.

\section{METODA}

Penelitian ini dilakukan di SD Negeri Kanisius Tlogosari Kulon Semarang pada bulan Juni 2012. Jenis penelitian deskriptif observasional dengan desain cross sectional dan termasuk lingkup gizi masyarakat.

Populasi dalam penelitian ini adalah semua siswa kelas 1- 6 SDN Kanisius Tlogosari Kulon Semarang. Pengambilan sampel dilakukan dengan metode simple random sampling, kemudian diperoleh jumlah sampel sebanyak 80 subyek.

Data yang dikumpulkan antara lain identitas sampel meliputi jenis kelamin dan usia subyek. Karakteristik orang tua, meliputi status pekerjaan orang tua, penghasilan dan pendidikan orang tua. Data asupan subyek dan gambaran kebiasaan konsumsi mie instan didapat melalui kuesioner food recall selama 3 hari.

Pengolahan dan analisis data menggunakan program Staistical Package for Social Sciense (SPSS) 17 for Windows. Analisis univariat dilakukan dengan memasukkan data yang diperoleh dalam tabel distribusi dan presentase.

\section{HASIL PENELITIAN \\ Gambaran Umum Subyek}

Sampel penelitian sebanyak 80 orang siswa SD dari kelas 1-6 SD. Data subyek dapat dilihat pada tabel 1 .

Tabel 1. Distribusi Gambaran Karakteristik Subyek Berdasarkan Jenis Kelamin dan Usia

\begin{tabular}{ccc}
\hline Gambaran Umum Responden & N & \% \\
\hline Jenis Kelamin & 34 & 42,5 \\
Laki-laki & 46 & 57,5 \\
perempuan & 80 & 100 \\
\hline Jumlah & & \\
Usia & 21 & 26,3 \\
$6-8$ th & 29 & 36,3 \\
$9-10$ th & 30 & 37,5 \\
\hline $11-12$ th & 80 & 100 \\
\hline Jumlah & &
\end{tabular}

Subyek terdiri dari laki-laki 34 sampel atau $42,5 \%$ dan perempuan 46 sampel atau sebesar $57,5 \%$. Subyek yang memiliki usia 11-12 tahun sebanyak 30 subyek $(37,5 \%)$.

\section{Kebiasaan Konsumsi Mie Instan}

Kebiasaan konsumsi mie instan meliputi data jumlah mie yang dikonsumsi selama 3 hari recall, frekuensi mengkonsumsi mie instan dalam seminggu, alasan mengkonsumsi mie instan dan penambahan bahan makanan lain. Data dapat dilihat pada tabel 3 .

Tabel 3. Distribusi Kebiasaan Subyek Mengkonsumsi Mie Instan

\begin{tabular}{ccc}
\hline Gambaran Konsumsi Mie Instan & $\mathbf{N}$ & $\mathbf{\%}$ \\
\hline Jumlah Konsumsi mie instan & & \\
Tidak makan & 20 & 25,0 \\
<3 bungkus & 51 & 63,8 \\
3-4 bungkus & 8 & 10,0 \\
\hline
\end{tabular}




\begin{tabular}{|c|c|c|}
\hline$>5$ bungkus & 1 & 1,3 \\
\hline Jumlah & 80 & 100 \\
\hline \multicolumn{3}{|l|}{$\begin{array}{c}\text { Frekuensi kebiasaan Konsumsi Mie } \\
\text { instan }\end{array}$} \\
\hline$<2 \mathrm{x}$ seminggu & 2 & 2,5 \\
\hline 2-3x seminggu & 70 & 87,5 \\
\hline$>4 x$ seminggu & 8 & 10,0 \\
\hline Jumlah & 80 & 100 \\
\hline \multicolumn{3}{|l|}{ Alasan Konsumsi Mie isntan } \\
\hline Praktis, mudah memasaknya & 27 & 33,8 \\
\hline Harga terjangkau & 7 & 8,8 \\
\hline Pengganti Nasi dan masakan lain & 5 & 6,3 \\
\hline Rasa enak & 9 & 11,3 \\
\hline Tertarik Iklan di TV & 4 & 5,0 \\
\hline Mengurangi Rasa Lapar & 9 & 11,3 \\
\hline Semua Alasan & 19 & 23,8 \\
\hline Jumlah & 80 & 100 \\
\hline \multicolumn{3}{|l|}{$\begin{array}{c}\text { Bahan Makanan Yang Dimasak } \\
\text { Bersama Mie Instan }\end{array}$} \\
\hline Mie instan & 50 & 62,5 \\
\hline Sayur & 3 & 3,8 \\
\hline Lauk Hewani & 11 & 13,8 \\
\hline Lauk Nabati & 1 & 1,8 \\
\hline Sayur dan Lauk Hewani & 8 & 10,0 \\
\hline Nasi & 7 & 8,8 \\
\hline Jumlah & 80 & 100 \\
\hline
\end{tabular}

Sebanyak 20 subyek $(25,0 \%)$ dalam 3 hari recall tidak mengkonsumsi mie instan. Sebanyak 8 subyek $(10,0 \%)$ memiliki frekuensi kebiasaan mengkonsumsi mie instan $>4 \mathrm{x}$ seminggu dan sebanyak 27 subyek $(33,8 \%)$ memberi alasan bahwa mie instan praktis dan mudah memasaknya. Sebanyak 50 subyek $(62,5 \%)$ mengkonsumsi mie instan tanpa penambahan bahan makanan lain.

\section{Gambaran Asupan Total Subyek}

Pada penelitian ini dilakukan recall selama 3 hari untuk melihat besar asupan total subyek. Gambaran asupan total subyek dikelompokkan menurut besar asupan energi, protein dan natrium total. Data dapat dilihat pada tabel 4.

Tabel 4 Distribusi Asupan Total

\begin{tabular}{cccccc}
\hline Besar Asupan & N & \% & Minimum & Maksimum & Mean \\
\hline Asupan Energi/hr & & & 502,53 & 1666,03 & 1091,8180 \\
$<1000 \mathrm{kkal}$ & 28 & 35,0 & & & \\
$1000-1500 \mathrm{kkal}$ & 49 & 61,3 & & & \\
$>1600 \mathrm{kkal}$ & 3 & 3,8 & & & \\
\hline Jumlah & 80 & 100 & & & \\
\hline Asupan Protein/hr & & & 12,66 & 57,98 & 32,6539 \\
$<45 \mathrm{gr}$ & 69 & 86,3 & & & \\
$45-49 \mathrm{gr}$ & 7 & 8,8 & & & \\
$>50 \mathrm{gr}$ & 4 & 5,0 & & & \\
\hline Jumlah & 80 & 100 & & & \\
\hline Asupan Natrium/hr & & & 19,73 & 2681,00 & \\
$<1000 \mathrm{mg}$ & 59 & 73,8 & & & \\
$1000-1900 \mathrm{mg}$ & 19 & 23,8 & & & \\
$>2000 \mathrm{mg}$ & 2 & 2,5 & & & \\
\hline Jumlah & 80 & 100 & & & \\
& & & & & \\
\hline
\end{tabular}


Asupan energi total yang $<1000$ kkal sebanyak 28 subyek $(35,0 \%)$, asupan protein total yang <45 gr sebanyak 69 subyek $(86,3 \%)$ dan asupan natrium total yang $<1000 \mathrm{mg}$ sebanyak 59 subyek $(73,8 \%)$.

\section{Gambaran Asupan Mie Instan Pada Subyek}

Gambaran asupan mie instan pada subyek dikelompokkan menurut besar asupan energi, protein dan natrium dalam mengkonsumsi mie instan. Data dapat dilihat pada tabel 5.

Tabel 5. Distribusi Asupan Energi, Protein dan Natrium Mie Instan

\begin{tabular}{cccccc}
\hline Besar asupan & $\mathbf{N}$ & $\mathbf{\%}$ & Minimum & Maksimum & Mean \\
\hline $\begin{array}{c}\text { Asupan Energi Mie } \\
\text { Instan/hr }\end{array}$ & & & & & \\
Tidak makan mie & 20 & 25,0 & $0 ., 00$ & 0,00 & 0,00 \\
$<300 \mathrm{kkal}$ & 49 & 61,3 & 61,67 & 76,67 & 165,853 \\
300-500 kkal & 9 & 11,3 & 315,00 & 493,33 & 380,740 \\
$>600 \mathrm{kkal}$ & 2 & 2,5 & 616,67 & 616,67 & 616,667 \\
\hline Jumlah & 80 & 100 & & & \\
\hline Asupan Protein Mie & & & & & \\
Instan/hr & & & & & \\
Tidak makan mie & 20 & 25,0 & 0,00 & 0,00 & 0,00 \\
$\quad<5$ gr & 41 & 51,3 & 1,17 & 4,67 & 2,918 \\
$5-10$ gr & 17 & 21,3 & 5,00 & 9,33 & 6,607 \\
$>11$ gr & 2 & 2,5 & 11,67 & 11,67 & 11,667 \\
\hline Jumlah & 80 & 100 & & & \\
\hline Asupan Natrium & & & & & \\
Mie Instan/hr & & & & & \\
Tidak makan mie & 20 & 25,0 & 0,00 & 0,00 & 0,00 \\
$<1000$ mg & 50 & 62,5 & 121,67 & 966,67 & 512,10 \\
1000-1900 mg & 8 & 10,0 & 1066,67 & 1786,67 & 1246,29 \\
$>$ >2000 mg & 2 & 2,5 & 2233,33 & 2233,33 & 2233,33 \\
\hline Jumlah & 80 & 100 & & & \\
\hline
\end{tabular}

Sebanyak 20 subyek $(25,0 \%)$ tidak mengkonsumsi mie instan selama 3 hari recall. Asupan energi mie instan yang <300 kkal sebanyak 49 subyek $(61,3 \%)$, asupan protein mie instan yang <5 gr sebanyak 41 subyek $(51,3 \%)$, asupan natrium mie instan yang $<1000 \mathrm{mg}$ sebanyak 50 subyek $(62,5 \%)$.

\section{Gambaran Konstribusi Asupan Energi, Protein dan Natrium Mie Instan}

Besar konstribusi energi, protein dan natrium mie instan terhadap asupan energi, protein dan natrium total dapat dilihat pada tabel 6 .

Tabel 6. Konstribusi Energi, Protein, Natrium Mie Instan Terhadap Asupan Total

\begin{tabular}{cccccc}
\hline Besar asupan & $\mathbf{N}$ & \% & Minimum & Maksimum & Mean \\
\hline Kontribusi Energi (\%) & & & & & \\
Tidak makan & 20 & 25,0 & 0,00 & 0,00 & 0,00 \\
$<20$ & 37 & 46,3 & 4,10 & 19,54 & 12,682 \\
$20-49$ & 20 & 25,0 & 21,22 & 44,51 & 27,935 \\
$>50$ & 3 & 3,8 & 51,02 & 61,58 & 56,966 \\
\hline Jumlah & 80 & 100 & & & \\
\hline Kontribusi Protein & & & & & \\
(\%) & 20 & 25,0 & 0,00 & 0,00 & 0,00 \\
Tidak makan & 41 & 50,0 & 2,44 & 14,99 & 8,823 \\
$<15$ & 16 & 20,0 & 15,22 & 30,75 & 23,181 \\
$15-39$ & 3 & 3,8 & 40,66 & 47,49 & 43,819 \\
\hline
\end{tabular}




\begin{tabular}{cccccc}
\hline$>40$ & \multicolumn{6}{c}{} & & & \\
\hline Jumlah & 80 & 100 & & & \\
\hline Kontribusi Natrium & & & & & \\
(\%) & 20 & 25,0 & 0,00 & 0,00 & 0,00 \\
Tidak makan & 5 & 5,0 & 33,68 & 46,72 & 40,482 \\
$<50$ & 18 & 22,5 & 50,80 & 69,89 & 61,709 \\
$50-69$ & 38 & 47,5 & 70,24 & 99,87 & 85,220 \\
$>70$ & & & & & \\
\hline Jumlah & 80 & 100 & & & \\
\hline
\end{tabular}

Sebanyak 20 subyek $(25,0)$. Konstribusi energi mie instan yang $<20 \%$ dari asupan energi total sebanyak 37 subyek $(46,3 \%)$, konstribusi protein mie instan yang $<15 \%$ dari asupan protein total sebanyak 41 subyek $(50,0 \%)$, dan konstribusi asupan natrium yang $>70 \%$ dari asupan natrium total sebanyak 38 subyek $(47,5 \%)$.

\section{PEMBAHASAN}

\section{Gambaran Umum Subyek}

Subyek merupakan anak sekolah dasar dimana terdapat 80 subyek yang terdiri dari $42,5 \%$ anak laki-laki dan $57 \%$ anak perempuan. Subyek yang masih duduk di kelas 1 dan 2 perlu bantuan orang tua untuk mengisi kuesioner, hal ini dikarenakan subyek masih belum paham mengenai maksud dan tujuan dari penelitian.

Pada anak usia 7-12 tahun anak memiliki karakteristik masa pertumbuhan yang tetap dan biasanya pada usia ini anak mulai terjadi peningkatan nafsu makan secara alamiah serta mereka sudah mampu memilih makanan yang mereka sukai. ${ }^{8}$

\section{Gambaran Kebiasaan Subyek Mengkonsumsi Mie Instan}

Untuk mengetahui kebiasaan konsumsi mie instan dilakukan dengan pengisian kuesioner dan food recall selama 3 hari. Dari data recall yang dilakukan selama 3 hari terdapat 20 subyek $(25,0 \%)$ tidak mengkonsumsi mie instan selama penelitian dilaksanakan dimana subyek yang tidak mengkonsumsi mie instan tadi memiliki frekuensi kebiasaan mengkonsumsi mie instan $<2 x$ seminggu sebanyak 1 subyek $(5,0 \%), 2-3 \mathrm{x}$ seminggu terdapat 17 subyek $(85,0 \%)$ dan yang memiliki frekuensi $>4 x$ seminggu sebanyak 2 subyek (10,0\%). Selain subyek yang tidak mengkonsumsi mie instan selama penelitian dilaksakanan terdapat pula subyek yang mengkonsumsi mie instan yaitu sebanyak 60 subyek $(75,0 \%)$. Menurut hasil data subyek yang mengkonsumsi mie instan terdapat 1 subyek $(1,3 \%)$ mengkonsumsi mie instan >5 bungkus karena subyek dalam sehari hanya mengkonsumsi mie instan saja, hal ini tentu tidak baik bagi kesehatan karena mie instan mengandung rendah protein dan rendah vitamin namun mengandung natrium yang tinggi sehingga apabila dikonsumsi secara berlebihan dapat menyebabkan kekurangan protein dan vitamin penting dalam tubuh serta dapat memberi resiko hipertensi akibat kelebihan asupan natrium.

Dalam penelitian ini subyek juga memberikan beberapa alasan mengapa mie instan sering mereka konsumsi. Subyek yang memberi alasan bahwa mie instan itu praktis dan mudah memasaknya dikarenakan subyek maupun orang tua subyek lebih ingin makanan yang cepat proses memasaknya sehingga tidak memerlukan waktu lama untuk menikmatinya. Terdapat pula subyek yang memberi alasan harga yang terjangkau, sehingga subyek yang memiliki keluarga berpenghasilan rendah juga dapat menikmati mie instan. Selain itu sebagian besar subyek, yaitu sebanyak 50 subyek $(62,5 \%)$ mengkonsumsi mie instan tanpa menambahkan bahan makanan lain sebagai pelengkap. Sedangkan 11 subyek $(3,8 \%)$ lebih suka menambahkan lauk hewani seperti sosis, bakso, ayam dan telur saat mengkonsumsi mie instan. Subyek yang tidak pernah memasak mie instan dengan bahan makanan lain seperti sayur, lauk hewani maupun lauk nabati akan memiliki asupan protein dan vitamin yang rendah, hal ini dikarenakan mie instan rendah protein dan vitamin.

Mie instan belum dapat dianggap makanan lengkap (wholesome food) karena belum mencukupi kebutuhan gizi yang seimbang bagi tubuh. Mie yang terbuat dari tepung terigu mengandung karbohidrat dalam jumlah besar, tetapi sedikit protein, vitamin dan mineral. Fungsi pemenuhan kebutuhan gizi mie instan hanya dapat diperoleh jika ada penambahan sayuran dan sumber protein. Jenis sayuran yang dapat ditambahkan adalah wortel, sawi, tomat, kol atau tauge. Sumber proteinnya dapat berupa telur daging, ikan, tempe atau tahu. ${ }^{9}$ 


\section{Gambaran Asupan Total Subyek}

Asupan energi dan protein subyek masih cukup rendah, hal ini dapat dilihat dari hasil distribusi asupan energi dan protein subyek yang masih banyak yang kurang dari kebutuhan gizi seharusnya. Asupan energi subyek paling rendah adalah sebanyak 502,53 kkal per hari dan asupan subyek paling banyak adalah 1666,03 kkal per hari. Sedangkan untuk asupan protein dengan nilai minimum protein yang dikonsumsi sebanyak 12 , $66 \mathrm{gr} / \mathrm{hr}$ dan nilai maksimum 57,98 gr/hr. Untuk asupan natrium subyek yang mengkonsumsi $<1000$ $\mathrm{mg} / \mathrm{hr}$ sebanyak 59 subyek $(73,8 \%)$ dan yang mengkonsumsi natrium $>2000 \mathrm{mg} / \mathrm{hr}$ sebanyak 2 subyek $(2,5 \%)$. Dilihat dari hasil recall didapat hasil bahwa asupan energi dan protein semua subyek masih rendah.

Kebutuhan energi pada usia 10-12 tahun relatif lebih besar daripada usia 6-9 tahun, karena terjadi pertumbuhan yang lebih cepat terutama pertumbuhan tinggi badan. Kebutuhan protein pada usia 7-9 tahun juga berbeda dengan usia 10-12 tahun. ${ }^{6}$ Kebutuhan energi anak usia 7-12 tahun yaitu 1800-2050 kkal/kg BB sedangkan untuk kebutuhan protein usia 7-12 tahun adalah 45-50 $\mathrm{gr} / \mathrm{kg}$ BB. Keseimbangan energi dicapai bila energi yang dikeluarkan sama dengan energi yang diterima. Apabila konsumsi energi melalui makanan kurang dari energi yang dikeluarkan, maka akan terjadi kekurangan energi. Kekurangan protein banyak ditemukan bersamaan dengan kekurangan energi, kondisi ini dapat menyebabkan malnutrisi yaitu marasmus sedangkan kekurangan protein murni pada stadium berat menyebabkan kwashiorkor pada anak-anak dan balita. ${ }^{10}$ Sedangkan kelebihan energi terjadi bila konsumsi energi melalui makanan melebihi energi yang dikeluarkan. Kelebihan energi akan diubah menjadi lemak tubuh, akibatnya terjadi berat badan lebih atau kegemukan. Kegemukan dapat menyebabkan gangguan dalam fungsi tubuh, merupakan risiko untuk dapat terjadi berbagai penyakit degeneratif. ${ }^{11}$

\section{Gambaran Asupan Mie Instan Serta Kontribusi Energi, Protein dan Natrium Pada Subyek}

Dari hasil data asupan subyek terdapat 20 subyek $(25,0 \%)$ tidak mengkonsumsi mie instan selama penelitian dilaksanakan sehingga subyek tersebut tidak memiliki data asupan dan kontribusi dari mie instan. Sedangkan 60 subyek $(75,0 \%)$ yang mengkonsumsi mie instan dapat dilihat hasil data asupan serta besar kontribusinya. Subyek yang memiliki asupan energi <300 kkal sebanyak
49 subyek (61,3\%) dengan kontribusi asupan energi minimum sebesar $4,10 \%$ dan kontribusi asupan energi tertinggi sebesar $61,58 \%$. Untuk asupan protein mie instan terdapat 41 subyek $(51,3 \%)$ memiliki asupan $<5$ gr dan sebanyak 2 subyek $(2,5 \%)$ subyek memiliki asupan protein mie instan sebesar $>11$ gr dengan kontribusi asupan protein terendah adalah $2,44 \%$ dan nilai kontribusi asupan tertinggi adalah sebesar $47,49 \%$. Hal ini menunjukkan bahwa mie instan memang rendah protein sehingga apabila dikonsumsi secara berlebihan dapat menyebabkan kekurangan protein dan hal ini sangat berbahaya bagi kesehatan dan pertumbuhan anak jadi perlu penambahan protein hewani maupun nabati dari bahan makanan lain sebagai pelengkap mie instan sehingga asupan protein subyek dapat terpenuhi dengan baik. Sebesar 50 subyek $(62,5 \%)$ memiliki asupan natrium $<1000 \mathrm{mg}$ dan 2 subyek $(2,5 \%)$ memiliki asupan natrium mie instan $>2000 \mathrm{mg}$ dengan kontribusi asupan natrium terendah adalah $33,68 \%$ dan nilai kontribusi asupan natrium tertinggi adalah sebesar 99,87\%. Dalam MSG yang terkandung dalam natrium dikonsumsi secara berlebihan akan sangat berbahaya dan membuat anak terbiasa mengkonsumsi mie instan yang memiliki rasa gurih sehingga tidak suka mengkonsumsi makanan yang dimasak di rumah terutama sayuran. ${ }^{13}$ Batas aman konsumsi natrium menurut Dietery Reference Intake (DRI) Natrium untuk anak usia 4-8 tahun adalah $1900 \mathrm{mg} / \mathrm{hr}$ sedangkan untuk usia 9-13 tahun adalah 2200 $\mathrm{mg} / \mathrm{hr}^{12}$

Mengkonsumsi mie instan juga dapat mengakibatkan obesitas (kegemukan). Hal ini dikarenakan mie mengandung karbohidrat sederhana, lemak, dan natrium tinggi. Sehingga jika dikonsumsi anak-anak secara terus menerus akan mengakibatkan obesitas, kenaikan kadar gula darah dan kenaikan tekanan darah. ${ }^{3}$

Dalam sebungkus mie instan terdapat bahan makanan tambahan seperti MSG sebagai penyedap rasa, natrium benzoat sebagai bahan pengawet, natrium tripolifosfat sebagai bahan pengembang. ${ }^{14}$ Batas aman konsumsi MSG di Indonesia sebesar 0,6 gr/hr. Penggunaan MSG < 2 gr tiap kali penyajian menimbulkan gejala Chinese Restaurant Syndrome (CRS) yang ditandai dengan rasa panas di dada, bagian belakang leher dan lengan bawah, sakit kepala, mual, jantung berdebar-debar, sesak nafas, dan sering mengantuk. ${ }^{10,14}$ BPOM memberi batasan konsumsi harian dari nipagin. Menurut Badan Pengawas Obat dan Makanan (BPOM), penggunaan nipagin 
di Indonesia diatur dalam Permenkes RI Nomor 722/Menkes/Per/IX/88 tentang bahan tambahan makanan yang mengizinkan penggunaan nipagin dalam kecap dengan batas maksimum 2550 $\mathrm{mg} / \mathrm{kg}{ }^{15}$ Kelebihan nipagin tidak memicu kanker namun jika dikonsumsi secara berlebihan akan menimbulkan gangguan fungsi hati. ${ }^{16}$

\section{SIMPULAN}

Sebagian besar siswa-siswi di SD Kanisius Tlogosari Kulon Semarang memiliki kebiasaan mengkonsumsi mie instan tanpa menambahkan bahan makanan tambahan lain sebagai pelengkap mie instan. Sebagian besar siswa-siswi di sekolah ini masih memiliki asupan energi dan protein total yang rendah karena kebutuhan energi anak usia 7 12 tahun sekitar 1800-2050 kkal/kg BB sedangkan protein sebesar 45-50 gr. Kontribusi asupan natrium masih tinggi yaitu sebagian besar masih memiliki kontribusi asupan natrium $>50 \%$ dari asupan natrium total. Sebanyak $87,5 \%$ siswa-siswi memiliki frekuensi kebiasaan mengkonsumsi mie instan 2-3x seminggu.

\section{SARAN}

Mie instan memiliki beberapa keuntungan namun juga memiliki kekurangan. Peran orang tua murid terutama ibu dalam menyiapkan makanan bagi anak sangat penting. Sebaiknya ibu dapat membantu anak dalam menyiapkan makanan yang sehat, aman serta bergizi. Peran kepala sekolah dan guru di lingkungan sekolah dapat memberi bimbingan kepada anak didiknya agar tidak sering mengkonsumsi mie instan.

\section{DAFTAR PUSTAKA}

1. Fermia, I.P. Gambaran Konsumsi Makanan Ringan pada Anak Sekolah di SD Cakra Depok tahun 2008: Depok. Fakultas Kesehatan Masyarakat Universitas Indonesia;2008.

2. Diana, Y. Kebiasaan Makan mie Instan Pada Mahasiswa Institut Pertanian Bogor dan Faktor Faktor Yang Mempengaruhinya. Bogor : Jurusan Gizi Masyarakat dan Sumberdaya Keluarga Fakultas Pertanian . Institut Pertanian Bogor; 2003.

3. Dewi, S. Kecukupan Energi Dan Protein Serta Sumbangan Energi Dan Protein Makanan Jajanan Pada Anak SD Negeri NO. 060822 Kecamatan Medan Area Tahun 2010. Medan : Fakultas Kesehatan Masyarakat Universitas Sumatera Utara; 2010.

4. Suhardjo, C. Berbagi Cara Pendidikan Gizi. Jakarta : Bumi Aksara; 2003.
5. Hoseney, R.C. Principles of Cereal Sciense and Technology, Third Edition. Manhattan, USA; St. Paul: 2010.

6. Almatsier S. Prinsip dasar ilmu gizi. Jakarta: PT Gramedia Pustaka Utama; 2003.

7. Park J, Le S, Jang AY, Chung HR and Kim J. A Comparison of Food and Nutrient Intake Betwen Instan Noodles Consumers and Non- Instan Noodles Consumers in Korean Adult. Nutrition Research and Practice (Nutr Res Parct); 2011.

8. Muhilal, Damayanti D. Gizi seimbang untuk anak sekolah dasar. Dalam: Hidup sehat dalam siklus kehidupan manusia. Jakarta: Gramedia Pustaka Utama; 2006.

9. Southeast Asia Food and Agricultural Science and Technology Center. Institut of Research and Community Empowerment. Bogor Agricultural University. November; 2010.

10. Kenney RA et al. Human Susceptibility to oral Monosodium L- glutamate. Am J din Nutrit (Feb) 1972, 25, pp 140-6.

11. Matondang, M . Status Gizi dan Pola Makan Pada Anak Taman Kanak-Kanak di Yayasan Muslimat R.A Al-Ittihadiyah Medan pada tahun 2007. Sumatera Utara : Universitas Sumatera Utara; 2009.

12. Proboprastowo SM, Cesilia MD. Angka kecukupan air dan elektrolit. Dalam Widyakarya Nasional Pangan dan Gizi VIII Jakarta; 2004.

13. Muhammad, Erfan. Analisis Proses Keputusan Pembelian Mie Instan Orang Tua Murid dan Faktor-Faktor Yang Mempengaruhi Murid Sekolah Dasar Dalam Mengkonsumsi Mie Instan. Bogor: Program Sarjana Ekstensi Manajemen Agribisnis Fakultas Pertanian Institut Pertanian Bogor; 2010.

14. Muchsin, Rosanti. Pengaruh Pemberian Monosodium Glutamate Terhadap Histologi Endometrium Mencit (Mus Musculus L). Medan : Sekolah Pasca Sarjana Universitas Sumatera Utara; 2009.

15. Herbet, Manurung. Analisis Bahan-Bahan Natrium benzoat Pada Bumbu Dan Kecap Mie Instan Secara Spektrofotometer. Universitas Sumatera Utara: 3 Juni; 2010. 